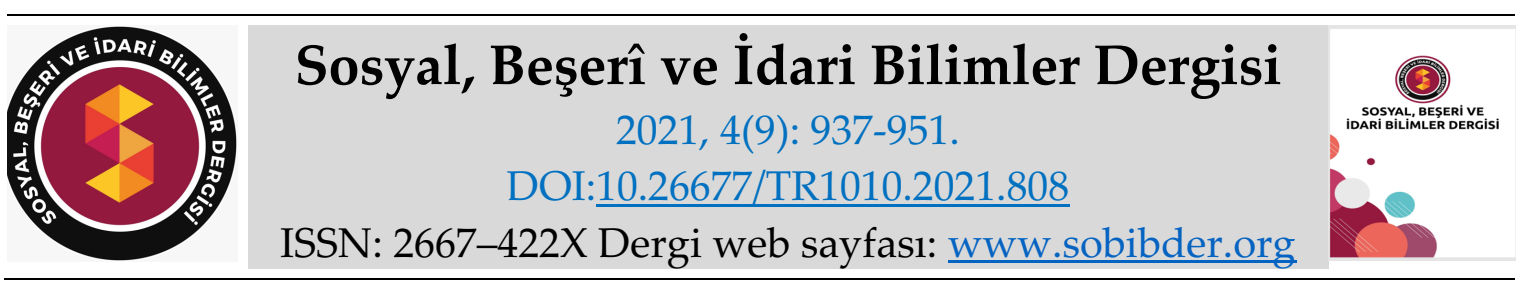

ARASTIRMA MAKALESI

\title{
Göçmen Kadınların Erzurum'da Yaşadığı Göçmenlik Deneyimleri Üzerine Nitel Bir Araştırma
}

Dr. Öğr. Üyesi Cengiz KILIÇ, Atatürk Üniversitesi, Açıöğretim Fakültesi, Erzurum, e-posta: cengiz.kilic@atauni.edu.tr ORCID: https://orcid.org/0000-0003-1640-0132

Dr. Öğr. Üyesi Derya ÇAKMAK KARAPINAR, Atatürk Üniversitesi, Açıöğretim Fakültesi, Erzurum, e-posta: derya.cakmak@atauni.edu.tr

ORCID: https://orcid.org/0000-0003-0796-1800

$\ddot{\mathrm{O} z}$

İnsanların yaşadıkları toplumdan ve çevreden daha iyi yaşam koşullarına sahip olmak ya da yaşadıkları yerdeki insanlardan uzaklaşarak daha güvenli bir yere geçme niyeti ile ayrılmaları olarak nitelendirilen göç günümüzde olduğu gibi tarih boyunca gözlemlenen bir olgudur. İnsanların, toplumların ve kültürlerin yapısal özelliklerinden kaynaklı olarak göç gibi göçe dair algıları ve göçe verdikleri tepkiler her ne kadar değişkenlik gösterse de göç, tüm insanlı̆̆ ilgilendiren ve tüm insanlığın yüzleşmek zorunda kaldığı en önemli toplumsal sorunlardan biridir. Bu sorun günümüzde uluslararası ilişkileri ve problemleri belirleyen en önemli maddelerin içerisinde yer almaktadır. Göç kendisi bir problemken kendi içinde de çocuk, kadın, hasta, engelli, yaşlı gibi özel grupların göçe bağlı olarak yaşadığı problemleri de bünyesinde barındırmaktadır. Bu çalışmada çeşitli nedenlerle yaşadıkları yerden ve bireylerden ayrılarak Erzurum'a göç eden kadınların karşılaştıkları ensarlık tutumlarını, göçmen kadın oldukları süreçte yaşadıkları duygusal ve sosyal yalnızlıkları ve bunun üzerinde etkili olan etmenleri ve kendilerinin ensar olmaları durumunda tutumlarının neler olabileceklerinin incelenmesi amaçlanmaktadır. Bu amaç doğrultusunda Erzurum'da göçmen olan kadınlara kar topu örnekleme yöntemi ile ulaşılmış olup derinlemesine mülakat yöntemi kullanılmıştır. Elde edilen veriler NVIVO 12 programı ile analiz edilmiştir. Analiz neticesinde göçmen kadınların genel olarak Erzurum halkının ensarlığından ve diğer göçmenlerle iletişimlerinden memnun olduğu, göç yolculuğuna başladıkları bireylerden Erzurum'a geldikten sonra bekledikleri manevi desteği alan ve alamayan göçmen kadınların olduğu, genel olarak çocuklarının eğitim ihtiyacını karşılamak amacıyla ve savaş nedeni ile can güveliklerinin olmaması nedeniyle Türkiye'ye göçtükleri ve bundan çok memnun oldukları, çok zor şartlarda göç ettikleri için ve diğer nedenlerle çalışmaya katılanların hemen hemen hepsinin ruhsal/psikolojik sorunları olduğu ve ailelerini ve vatanlarını oldukça özledikleri görülmüştür. Ayrıca kendilerinin ensar olma durumunda göçmen kadınlara daha merhametli ve iyi davranacaklarını dile getirdikleri de görülmüştür. Türkiye'de göçmenlerin yerel halkın hem kültürü hem de iş imkanları açısından birer tehdit olarak görülmesine karşın Erzurum'da yaşayan kadınların yerli halktan memnun oldukları, ancak çocuklarının dışlanmaya maruz kaldığı ve dayak yediği sonucuna ulaşılmıştır. Gerçekleştirilen bazı çalışmalar ebeveynlere yönelik sosyal dışlanmayı çocukların kendi üzerlerinde hissettiği ve göçmen öğrencilerin akranları tarafından doğrudan sosyal dışlanmaya maruz kaldıklarını ortaya koymuşlardır.

Anahtar Kelimeler: Göç, Göçmen Kadın, Sosyal ve Duygusal Yoksunluk.

Makale Gönderme Tarihi: 17.06.2021

Makale Kabul Tarihi: 03.09.2021

\section{Önerilen Atıf:}

Kılıç, C. ve Çakmak Karapınar, D. (2021). Göçmen Kadınların Erzurum'da Yaşadığı Göçmenlik Deneyimleri Üzerine Nitel Bir Araştırma, Sosyal, Beşeri ve İdari Bilimler Dergisi, 4(9): 937-951.

(C) 2021 Sosyal, Beşerî ve İdari Bilimler Dergisi. 


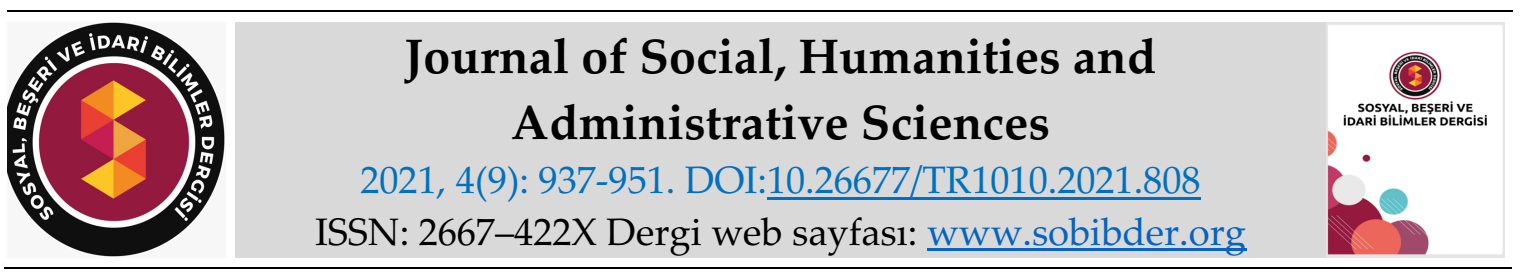

RESEARCH PAPER

\title{
A Qualitative Research on The Migration Experiences of Migrant Women in Erzurum
}

Assistant Prof. Dr. Cengiz KILIÇ, Atatürk University, Distance Education Faculty, Erzurum, email: cengiz.kilic@atauni.edu.tr ORCID: https://orcid.org/0000-0003-1640-0132

Assistant Prof. Dr. Derya ÇAKMAK KARAPINAR, Atatürk University, Distance Education Faculty, Erzurum, e-mail: derya.cakmak@atauni.edu.tr ORCID: https://orcid.org/0000-0003-0796-1800

\begin{abstract}
Migration, which is defined as the departure of people from the society and environment they live in with the intention of having better living conditions or moving away from the people where they live, with the intention of moving to a safer place, is a phenomenon observed throughout history as it is today. Although people's perceptions and reactions to migration, such as migration, vary due to the structural characteristics of societies and cultures, migration is one of the most important social problems that concern all humanity and that all humanity has to face. Today, this problem is among the most important items that determine international relations and problems. While migration itself is a problem, it also includes the problems experienced by special groups such as children, women, sick, disabled and elderly people due to migration. In this study, it is aimed to examine the attitudes of the women who migrated to Erzurum by leaving their place of residence and individuals for various reasons, the emotional and social loneliness they experienced during the process of being a migrant woman and the factors that affect this, and what their attitudes might be if they become a host. For this purpose, immigrant women in Erzurum were reached by snowball sampling method and in-depth interview method was used. The obtained data were analyzed with the NVIVO 12 program. As a result of the analysis, migrant women are generally satisfied with the hosting of the people of Erzurum and their communication with other immigrants, there are those who receive the moral support they expect after coming from the individuals they have started to migrate, and those who do not, and they migrate to Turkey in order to meet their children's education needs and because of the lack of safety because of the war. It was observed that almost all of those who participated in the study because they were very satisfied, migrated under very difficult conditions and for other reasons had mental/psychological problems and missed their families and homeland very much. It was also seen that they expressed that they would treat immigrant women very compassionately and well if they became host. It has been concluded that the women living in Erzurum are satisfied with the local people, but their children are exposed to exclusion and beaten, as immigrants are seen as a threat in terms of both culture and job opportunities of the local people in Turkey. Some studies have revealed that children feel the social exclusion of parents on themselves and that immigrant students are directly exposed to social exclusion by their peers.
\end{abstract}

Keywords: Migration, Migrant Women, Social and Emotional Deprivation.

Received: 17.06 .2021

Accepted: 03.09.2021

Suggested Citation:

K1lıç, C. and Çakmak Karapınar, D. (2021). A Qualitative Research on The Migration Experiences of Migrant Women in Erzurum, Journal of Social, Humanities and Administrative Sciences, 4(9): 937-951.

(c) 2021 Sosyal, Beşerî ve İdari Bilimler Dergisi. 


\section{Gíriş}

İçinde bulunduğumuz çağ, küreselleşmenin birden fazla süreci kapsaması ile birlikte dünya çapında giderek artan uluslararası göç hareketliliğinin 'göçler çağı' olarak nitelendirilmesine neden olmuştur. Buradan hareketle küreselleşme sonucunda ortaya çıkan göç hareketi, göç alan ve veren ülkelerin ulusal egemenlik ve güvenliğini doğrudan etkileyen bir konu olmaksızın uluslararası düzeyde ilişkileri çok boyutlu etkilemektedir. Bu minvalde, uluslararası göçe katılan insan sayısındaki düzenli artış sonucunda toplam sayı 258 milyonu bulmuştur (United Nations, 2017).

İnsanın yaşadığı coğrafyadan ve kültürden ayrılıp başka bir mekâna göç etmesi ait olduğu sosyal gruptan bağımsız olarak ciddi etkiler yaratabilmektedir. Bu etkilerin içeriği kısmen olumlu iken (sağlık imkanlarına kavuşabilme, iyi bir eğitim alabilme durumu) öte yandan olumsuz (göç esnasında karşılaşılan riskler, adaptasyon problemleri, travma, istismar) olabilmektedir. Genel olarak bakıldığında bu süreçten bazı alt gruplar diğerlerine göre daha fazla etkilenebilmekte, daha kırılgan olabilmekte; özellikle kadınlar, insan ticareti gibi bir insanlık suçunun odağı haline gelebilmektedirler (UNODC, 2016).

Kadın göçmenlerin neden ve nasıl göç ettikleri, göç esnasında karşılaştıkları problemler ve göç olgusunun kadınlar üzerindeki etkisinin araştırılması önem arz etmektedir. Mollard'a (2010) göre; yoksulluk, güvenlik sorunları, evlilik, iş gücü, emek farklılıkları, yurt dışı bağlantıları kadın göçünün temel sebepleri olarak ele alınabilir. Genel olarak göç sınıflandırmaları, benzer biçimde kadın göçü öncelikle 'istekli bir biçimde gerçekleştirilen diğer bir deyişle zorlayıcı diş faktörlerden bağımsız göçler' ve 'zorunlu bir biçimde yapılan göçler' olmak üzere iki ana gruba ayrilmaktadır.

Çeşitli nedenlerle yaşadıkları yerden ve bireylerden ayrılarak Erzurum'a göç eden kadınların karşılaştıkları ensarlık tutumlarını, göçmen kadın oldukları süreçte yaşadıkları duygusal ve sosyal yalnızlıkları ve bunun üzerinde etkili olan etmenleri ve kendilerinin ensar olmaları durumunda tutumlarının neler olabileceklerinin incelenmesi amaçlayan bu çalışmada 14 göçmen kadınla görüşmeler gerçekleştirilmiştir ve NVIVO 12 paket programıyla analiz edilmiştir.

\section{GÖÇ ve KADIN}

Göç, genel itibariyle 'anlamlı uzaklık ve etki oluşturabilecek kadar bir zaman dilimi içerisinde gerçekleşen tüm yer değiştirmeler' olarak tanımlanabilir (Erder, 1986). Bu tanımda da belirtildiği üzere bu geniş perspektif göç konusunun anlaşılmasını güçleştiren konuların başında yer almaktadır. Bu durumun etkisiyle yakın tarihe kadar göç ve göçmenler, toplumsal cinsiyet, çocuk, kadın, aile gibi konularda bağımsız düşünülmüştür. Bu doğrultuda, göç araştırmalarında göçmenler kimliksiz bireyler olarak yer almışlardır. Bu indirgemeci yaklaşım genel itibariyle göçün ve farklı sosyal gruplar üzerinde yarattığı etkinin anlaşılmasını zorlaştırmıştır.

BM Mülteciler Yüksek Komiserliği'nin (BMYK) verilerine göre 65,6 milyon insanın ülkelerinde yaşadıkları bölgelerden göç etmek zorunda kaldıkları anlaşılmaktadır. Ülkeleri dışında sığınma arayan nüfusun ise 22,5 milyon civarında olduğunu belirtmektedir (UNHCR, 2018). BMYK'ya göre; göçmenler cinsiyetleri açısından gruplandırıldığında erkek göçmenler dünya genelinde toplamda yaklaşık \%2'lik bir farkla en büyük göçmen kitlesini oluşturmaktadır. Kadın göçmenlerin oransal olarak büyüklüğü yeni bir olgu olmayıp neredeyse 1960'lardan itibaren kadınların göç bağlamındaki payı erkeklere oldukça yakın bir seyirde ilerlemektedir. Kadın göçmenler durumu yaş grupları ve göç edilen ülkelerin gelişmişlik düzeyine göre incelendiğinde ise ekonomik olarak gelişmiş ülkelerde 30-60 yaş aralığında olduğu anlaşılmaktadır (Yılmaz, 2019). 
Göçün yönünün ekonomik ve sosyal gelişmişlik anlamında daha ileri düzeyde ülkelere doğru gerçekleştirilmesi kültürel farklılıklar, geri gönderilme kaygısı, kayıt dışılık gibi olumsuz etkiler bir tarafa bırakıldığında daha iyi bir eğitim ve sağlık şartlarına ulaşım da mümkün olabilmektedir. Örneğin; Dünya Bankasının bir araştırmasına göre, Guetemala, Meksika ve Fas'ta kadınların göç ile birlikte daha iyi sağlık imkânlarına kavuşması bu anlamda bilgi seviyelerindeki artış, anne ve bebek ölüm oranlarının düşmesini sağlayabilmektedir. Diğer yandan kırdan kente göç çocuk ölümlerini negatif olarak etkilemektedir (Fleury, 2016).

Göçün bireyler üzerindeki olumsuz etkileri düşünüldüğünde özellikle kadınlar açısından toplumsal anlamdaki rol ve sorumluluklarının yanı sıra ekonomik, sosyal ve kültürel kayıpların da birçok anlamda yoksunluğa sebebiyet verdiği aşikârdır. Dolayısıyla bu meselenin kadınlar üzerindeki etkilerinin farklı boyutlarıyla ele alınması önem arz etmektedir.

\section{MATERYAL ve YÖNTEM}

\section{Araştırmanın Amacı}

İnsanların, toplumların ve kültürlerin yapısal özelliklerinden kaynaklı olarak göç gibi göçe dair algıları ve göçe verdikleri tepkiler her ne kadar değişkenlik gösterse de göç, tüm insanlığ ilgilendiren ve tüm insanlığın yüzleşmek zorunda kaldığı en önemli toplumsal sorunlardan biridir. Göç kendisi bir problemken kendi içinde de çocuk, kadın, hasta, engelli, yaşlı gibi özel grupların göçe bağlı olarak yaşadığı problemleri de bünyesinde barındırmaktadır. Bu çalışmada çeşitli nedenlerle yaşadıkları yerden ve bireylerden ayrılarak Erzurum'a göç eden kadınların karşılaştıkları ensarlık tutumlarını, göçmen kadın oldukları süreçte yaşadıkları duygusal ve sosyal yalnızlıkları ve bunun üzerinde etkili olan etmenleri ve kendilerinin ensar olmaları durumunda tutumlarının neler olabileceklerinin incelenmesi amaçlanmaktadır.

\section{Araştırmanın Önemi}

$\mathrm{Bu}$ araştırmada ele alınan göç olgusu; birçok toplumsal normların sosyal hayattaki görünürlüğünü arttırdığı bilinmektedir. Buradan hareketle, Erzurum ilinde toplumsal doku itibariyle toplumsal cinsiyet kalıp yargılarının, cinsiyete dayalı ayrımcılığının ve kadının iş gücüne katılımının farklı boyutlarda ele alınması önem arz etmektedir.

Göç sürecinin cinsiyet farklılıkları önemsenerek incelenmesi ve göçün asıl aktörünün aileyi kamusal alanda temsil edenin erkek olduğu ön kabulü ile gerçekleştirilen çalışmaların, kadını ikinci planda tuttuğu bilinmektedir. Dolayısıyla göç sürecindeki kadının, erkeklerden ayrı ve kendine özgü durumuyla ele alınıp incelenmesi gerekmektedir.

\section{Araştırmanın Kapsamı ve Sınırlılıkları}

Göçmen kadınların Erzurum'da yaşarken hissettikleri sosyal ve duygusal yoksunluğu ve nedenlerini ortaya koymaya yönelik olarak planlanan bu çalışmada Afgan uyruklu göçmen kadınlara ulaşılmış ve çalışma kapsamında görüşme gerçekleştirilmiştir. Bu araştırma;

- Örneklem içerisinde yer alan 28 göçmen kadının çeşitli nedenlerden dolayı çalışmaya katılmak istememesi ve çalışmaya katılmaya gönüllü olarak katılan 14 göçmen kadınla,

- Araştırmanın belli bir zaman aralığında gerçekleştirilmiş olması nedeniyle zamanla göçmen kadınların görüş, düşünce, fikir ve beklentilerinin değişme ihtimalinin bulunmasiyla, 
- Elde edilen bulguların katılımcıların verdiği cevapların analizi sonucunda ortaya çıkmasıyla,

- Literatürde göçmen kadınların sosyal ve duygusal yoksunluklarını inceleyen çalışmaların bulunmamasıyla sınırlıdır.

\section{Araştırmanın Yöntemi}

Çeşitli nedenlerle yaşadıkları yerden ve bireylerden ayrılarak Erzurum'a göç eden kadınların karşılaştıkları ensarlık tutumlarını, göçmen kadın oldukları süreçte yaşadıkları duygusal ve sosyal yalnızlıkları ve bunun üzerinde etkili olan etmenleri ve kendilerinin ensar olmaları durumunda tutumlarının neler olabileceğine odaklanılması nedeniyle nitel araştırma yöntemi esaslı bir çalışma yürütülmüştür.

Nitel araştırma yöntemi nitel veri toplama yöntemleri kullanılarak gerçekleştirilen ve olay, olgu ve durumların doğal ortamlarında bütüncül bir biçimde ortaya konmasını sağlayan araştırma sürecidir (Yıldırım ve Ş̧imșek, 2008). Nitel araştırmada olaylar, olgular ya da sorunlar meydana geldiği çevre, değerler ve algı bağlamında incelenerek ilişki ağını saptamayı ve kuram oluşturmayı içeren çalışmalardır. Nitel araştırmalarda nicel araştırmaya göre daha az sayısal ve istatistiki verilerle ifadeye başvurulmaktadır. Elde edilen verilerin sözlü ya da yazılı analizlerine ağırlık verilmektedir (Neuman, 2012).

Bu çalışmada araştırma deseni olarak araçsal durum çalışması kullanılmıştır. Nitel durum çalışmaları bir ya da birkaç duruma ilişkin etmenlerin gözlem ya da mülakat aracılı̆̆ıyla derinlemesine araştırılarak duruma olan etkileri üzerine odaklanır. Nitel çalışmalarda yaygın olarak kullanılan durum çalışmasının deseni durumun türü, sayısı ve içeriğine göre farklı türlere ayrılmaktadır (Yıldırım ve Şimşek, 2016; Creswell, 2013). Nitel durum çalışmalarından biri olan araçsal durum çalışması tek bir konu veya bir soruna odaklanıldığında kullanılmaktadır. Bu araştırmada göçmen kadınların Erzurum'da yaşadıkları sosyal ve duygusal yoksunluğun tespitine odaklanılmıştır.

\section{Araştırmanın Örneklemi}

Araştırmanın evrenini Erzurum'da yaşayan göçmen kadınlar oluşturmaktadır. Araştırmanın evreninden örneklem grubu belirleyebilmek amaciyla kartopu/zincir örnekleme yöntemi kullanılmıştır. Kartopu/zincir örnekleme yönteminde araştırmanın yapılacağı bireylerden ilkine ulaşılması ile başlar ve görüşme sonunda görüşme yapılan bireyin önerdiği/yönlendirdiği diğer birey/bireylere ulaşılır ve aynı şekilde görüşme sonunda onunda önerdiği/yönlendirdiği diğer birey/bireylere ulaşılır. Böylece araştırmaya katılan katılımcı sayısı artarak çalışma süreci devam eder (Koç Başaran, 2017). Bu çalışmada öncelikle görüşmenin gerçekleştirileceği ilk göçmen kadına ulaşılmıştır. Afgan uyruklu olan göçmen kadın görüşme sonunda diğer göçmen Afgan kadınları ve onlar da diğer göçmen Afgan kadınları önermiştir. Bu şekilde 28 Afgan uyruklu göçmen kadına ulaşılmıştır. Ancak araştırmaya katılmaya gönüllü 14 göçmen Afgan kadın olduğu için araştırmanın örneklemini bu 14 göçmen kadın oluşturmuştur.

\section{Araştırma Soruları}

Göç, göçmen kadın ve sosyal ve duygusal yoksunluk konuları bağlamında incelenen ilgili literatür çerçevesinde araştırmanın amacı ve çalışma kapsamında aşağıdaki araştırma soruları ortaya konmuş ve bu sorulara yanıt aranmıştır. 
Araştırma Sorusu 1: Göçmen kadınların Erzurum halkı ve diğer göçmenlerle kurdukları iletişimin sosyal ve duygusal yalnızlıkları üzerine etkileri nedir?

Araştırma Sorusu 2: Göçmen kadınların aldıkları manevi desteklerin sosyal ve duygusal yalnızlıkları üzerine etkileri nedir?

Araştırma Sorusu 3: Göçmen kadınların göç etmiş olmalarına ilişkin duygu ve düşüncelerinin sosyal ve duygusal yalnızlıkları üzerine etkileri nedir?

Araştırma Sorusu 4: Göçmen kadınların sosyal ve duygusal yalnızlıklarının kendilerinin ev sahibi olmaları durumundaki düşünce ve davranışları üzerine etkileri nedir?

Araştırma Sorusu 5: Göçmen kadınların yaşadıkları sosyal ve duygusal yalnızlığın duygu durum ve davranışlarına etkileri nedir?

\section{Veri Toplama Araçları, Süreci ve Analizi}

Veri toplama sürecinde öncelikle göç, göçmen kadınlar ve sosyal duygusal yalnızlık konu alanlarında literatür taranmış, yazılı ve görüntülü belgeler tespit edilerek incelenmiş ve buna bağlı olarak bir görüşme formu hazırlanmıştır. Hazırlanan görüşme formuna son hali verilmeden önce dil ve alan uzmanlarınca gerekli incelemeler yapılmış ve düzenlemeler gerçekleştirilmiştir. Son hali verilen yarı yapılandırılmış görüşme formu aracılığıyla örneklem içerisine dahil edilen 28 göçmen kadın ile araştırmanın yürütülmesi hedeflenmiştir. Çalışmaya Afgan uyruklu 14 göçmen kadın katılmaya gönüllü olmuş ve çalışma 14 göçmen kadınla yürütülmüştür. Göçmen kadınlar ile gerçekleştirilen görüşmelerin transkripti çıkarılmış ve nitel veri analizi için uygun hale getirilmiştir. Ardından elde edilen tüm görüşme transkriptleri NVIVO 12 programına aktarılmış ve belli kodlar çerçevesinde kodlanmıştır'1. Kodlama işleminden sonra veriler tekrar gözden geçirilmiş ve kodlamalarda birleştirmelere ya da ayrımlara gerek olup olmadığ denetlenmiş ve katılımcıların görüşme sorularına verdikleri cevaplar ve belirttikleri görüşler içerik analizi yöntemiyle çözümlenmiştir.

\section{BULGULAR}

Çalışmanın bu bölümünde göçmen kadınların yaşadıkları sosyal ve duygusal yoksunluğu saptamak amacıyla gerçekleştirilen alan araştırmasına ilişkin bulgular sunularak yorumlanmıştır. Araştırma soruları çerçevesinde elde edilen verilerin analizi sonucunda ortaya çıkan bulgular ilgili başlıklar altında sunulmuştur.

Çalışma Mayıs 2021-Haziran 2021 tarihleri arasında gerçekleştirilmiştir. Çalışmaya katılan göçmen kadınların \%57,14'ü $(\mathrm{N}=8)$ 20-29 yaş aralığında, \%21,43’ü $(\mathrm{N}=3)$ 30-39 yaş aralığında, $\% 14,29^{\prime}$ u $(\mathrm{N}=2)$ 40-49 yaş aralığında ve \%7,14'ü (N=1) 60-69 yaş aralığında yer almaktadır. Ayrıca çalışmaya katılan göçmen kadınların tümü Afgan uyrukludur ve \%85,71'i evli ve \%14,29'u

\footnotetext{
${ }^{1}$ Elde edilen nitel verilerin analizi üç ana aşamada gerçekleştirilmiştir. Birinci aşamada veriler bir araya toplanarak araştırmanın amacına uygun olarak anlamlı kodlara ayrılmıştır. Tüm verileri kodlama işlemi gerçekleştirildikten sonra bir kod listesi oluşturulmuştur. Kod listesi ile veriler karşılaştırmalı olarak incelenmiş ve kodlar ile verilerin tutarlılığı sağlanmıştır. Ayrıca kodlar benzerlik ya da ortak özellik yönünden de incelenmiş ve kodlarda birleştirmelere gitmeye gerek olup olmadığına karar verilmiştir. Son hali verilen kodlar her bir araştırma sorusu altında ayrıntılı şekilde açıklanarak yorumlanmıştır.
} 
bekardır. Bekar bireylerden biri göç ettikten sonra eşinden gördüğü şiddet neticesinde eşinden ayrılmıştır. Göçmen kadınların eğitim seviyelerine bakıldığında ise \%35,71'inin (N=5) okumadığı, \%42,86'sının (N=6) ilköğretim mezunu olduğu, \%14,29'unun $(\mathrm{N}=2)$ orta öğretim mezunu olduğu ve \%7,14'ünün (N=1) halen okumaya devam ettiği görülmüştür. Göçmen kadınların 92,86'sının (N=13) göç yolculuğuna eşi ve çocukları ile başladığı ve \%7,14'ünün (N=1) göç yolculuğuna tek başladığı tespit edilmiştir. Bunlara ek olarak göçmen kadınların \%21,43'ünün (N=3) 2 çocuğuyla, \%21,43'ünün (N=3) 3 çocuğuyla, \%21,43'ünün (N=3) 4 çocuğuyla, \%14,29'unun ( $\mathrm{N}=2) 5$ çocuğuyla, \%14,29'unun ( $\mathrm{N}=2) 6$ çocuğuyla ve \%7,14'ünün ( $\mathrm{N}=1$ ) çocuksuz olarak göç ettiği saptanmıştır. Bunlara ek olarak göçmen kadınların \%14,29'unun ( $\mathrm{N}=2)$ 1 yıldır, \%7,14'ünün ( $\mathrm{N=1}) 2$ yıldır, \%28,57'sinin ( $N=4) 3$ yıldır, \%21,43'ünün (N=3) 4 yıldır, $\% 21,43$ 'ünün (N=3) 5 yıldır ve \%7,14'ünün (N=1) 1 yıldır Erzurum'da olduğu görülmüştür (Bkz Tablo 1).

Tablo 1. Göçmen Kadınların Demografik Bilgileri

\begin{tabular}{|c|c|c|c|c|c|c|c|}
\hline $\begin{array}{l}\text { Yaş } \\
\text { Aralığı }\end{array}$ & Uyruğu & Cinsiyeti & $\begin{array}{c}\text { Vatanından } \\
\text { Ayrı } \\
\text { Olduğu } \\
\text { Süre (Yıl) } \\
\end{array}$ & $\begin{array}{l}\text { Medeni } \\
\text { Durumu }\end{array}$ & $\begin{array}{c}\text { Kimlerle Göç } \\
\text { Ettiği }\end{array}$ & $\begin{array}{l}\text { Eğitim } \\
\text { Düzeyi }\end{array}$ & $\begin{array}{l}\text { Çocuk } \\
\text { Sayısı }\end{array}$ \\
\hline $20-29$ & Afgan & Kadın & 2 & Evli & Eşi ve çocukları & Okumamış & 2 \\
\hline $20-29$ & Afgan & Kadın & 3 & Evli & Eşi ve çocukları & İlköğretim & 2 \\
\hline $20-29$ & Afgan & Kadın & 4 & Evli & Eşi ve çocukları & İlköğretim & 2 \\
\hline $40-50$ & Afgan & Kadın & 5 & Evli & Eşi ve çocukları & Okumamiş & 3 \\
\hline $20-29$ & Afgan & Kadın & 1 & Evli & Eşi ve çocukları & Okumamiş & 3 \\
\hline $20-29$ & Afgan & Kadın & 5 & Evli $^{*}$ & Eşi ve çocukları & İlköğretim & 5 \\
\hline $20-29$ & Afgan & Kadın & 3 & Evli & Eşi ve çocukları & Okumamış & 4 \\
\hline $30-39$ & Afgan & Kadın & 4 & Evli & Eşi ve çocukları & Okumamış & 6 \\
\hline $30-39$ & Afgan & Kadın & 6 & Evli & Eşi ve çocukları & İlköğretim & 6 \\
\hline $60-70$ & Afgan & Kadın & 4 & Evli & Eşi ve çocukları & $\begin{array}{l}\text { Orta } \\
\text { öğretim }\end{array}$ & 4 \\
\hline $40-50$ & Afgan & Kadın & 3 & Evli & Eşi ve çocukları & İlköğretim & 5 \\
\hline $20-29$ & Afgan & Kadın & 1 & Bekar & Tek & Okuyor & - \\
\hline $20-29$ & Afgan & Kadın & 3 & Evli & Eşi ve çocukları & $\begin{array}{c}\text { Orta } \\
\text { öğretim }\end{array}$ & 3 \\
\hline $30-39$ & Afgan & Kadın & 5 & Evli & Eşi ve çocukları & İlköğretim & 4 \\
\hline
\end{tabular}

*şiddet mağduru olduğu için ayrılmış.

\section{Göçmen Kadınların Erzurum Halkı ve Diğer Göçmenlerle Kurdukları İletişimin Sosyal ve Duygusal Yalnızlıkları Üzerine Etkileri}

Erzurum'da yaşayan göçmen kadınların sosyal ve duygusal yalnızlıkları üzerine etkilerini belirlemek amacıyla görüşme gerçekleştirilen göçmen kadınlara "Yerel halkla arkadaşlık kurmada yaşadığınız sıkıntılar nelerdir?", "Diğer mültecilerle arkadaşlık kurmada yaşadığınız sıkıntılar nelerdir?" ve "Yerel halktan insanların sizi anladığını düşünmenizi sağlayan tutum ve davranışları nelerdir?" görüşme soruları sorulmuştur. Görüşmeye katılmayı kabul eden göçmen kadınların tamamı bu sorulara cevap vermişlerdir. 
Yerel halkla arkadaşlık kurmada yaşadı̆̆ınız sıkıntılar nelerdir? sorusuna çalışmaya katılan göçmen kadınların çoğunluğu bir sıkıntı yaşamadıklarını yani "memnun olduklarını" (N=7- \%50,00) hatta az veya çok "Türk arkadaşlarının olduğunu" $(\mathrm{N}=3-\% 21,43)$ ifade ederken çocuklarının "dışlamaya maruz kaldığını dayak yediğini" ( $\mathrm{N=3-} \% 21,43)$ ve ev kiralama ve para iadesi konularında sıkıntı yaşadıklarını $(\mathrm{N}=1-\% 7,14)$ söyleyen göçmen kadınlar da olmuştur. Göçmen kadınların yerel halkla arkadaşlık kurmada yaşadığı sıkıntılarla ilgili bazı ifadeleri aşağıdaki gibidir;

Sıkıntılarım var. Çocuklarımı kuran kursundan attılar. Çünkü başka bir çocuk ben bunları burada istemiyorum dedi. GK3

Şu sıkıntılarım var. Ben en kiraladım bana dediler $2000 t l$ peşin ver. Paranı çıtı̆̆ın zaman geri veririm. Ben 2 ay kaldım sonra çıktım. Ama paramı geri vermedi. GK4

Bir sıkıntım yok ama bazen Türk çocukları çocuklarımı dövüyor ve dışlıyor. GK6

Hayır ben herkesten çok memnunum bana destek oluyorlar. GK10

Hayır ben bazen çocuklarımı dövüyorlar ama ben onu hallediyorum. GK11

Hayır yok hatta benim Türk arkadaşlarım bile var. GK14

Diğer mültecilerle arkadaşlık kurmada yaşadı̆̆ınız sıkıntılar nelerdir? sorusuna çalışmaya katılan göçmen kadınların tamamı diğer mültecilerle arkadaşlık kurmada bir sıkıntı yaşamadığını dile getirmiştir. Göçmen kadınların diğer mültecilerle arkadaşlık kurmada yaşadığı sıkıntılarla ilgili bazı ifadeleri aşă̆ıdaki gibidir;

Hayır diğer mültecilerle ilgili bir sıkıntı yaşamadım. GK4

Yok çok iyi geçiniyoruz. GK5

Hayır ben onlardan memnunum. GK9

Yerel halktan insanların sizi anladığını düşünmenizi sağlayan tutum ve davranışları nelerdir? sorusuna çalışmaya katılan göçmen kadınların bir kısmı yerel halkın kendilerine "çok yardımcı olduklarını" ( $\mathrm{N}=10-\% 66,66)$ ve kendilerini "çok sevdiklerini" $(\mathrm{N}=2-\% 13,33)$ bu nedenle "anladıklarını düşündüklerini" (N=1- \%6,67) ifade ederken diğer kısmı yerel halkın "bazılarının anladığını bazılarının anlamadığını" (N=1- \%6,67) ifade etmiştir. Ayrıca yerel halkın kendilerini "hiç anlamadığını" (N=1- \%6,67)2 düşünenlerin de olduğu görülmüştür. Göçmen kadınların yerel halkın kendilerini anlama durumlarına dair düşünceleri ile ilgili bazı ifadeleri aşağıdaki gibidir;

Evet, bizi anliyorlar. Bizi çok seviyorlar. Illk geldiğimiz zamanla bizim maddi durumumuz iyi değildi bize yardımcı oldular. GK3

Evet, bizi anlıyorlar. Illk geldiğim zamanlar eczanede çalı̧̧an bir adam vardı bize çok yardımcı oldu. GK2

Evet, anlıyorlar. İlk geldiğim zamanlar çok yardımda bulundular. GK6

Bizi anladıklarını düşünüyorum. Bana çok yardımcı oldular her konuda. GK8

İlk geldiğim zaman bana ev eşyası ve mutfak eşyası verdiler. Yani bizi anlıyorlar. GK7

\footnotetext{
2 Çalışmaya katılan göçmen kadınlardan yerel halkın kendilerini anlama durumlarına dair birden fazla düşünceden bahseden bulunmaktadır.
} 


\section{Göçmen Kadınların Aldıkları Manevi Desteklerin Sosyal ve Duygusal Yalnızlıkları Üzerine Etkileri}

Erzurum'da yaşayan göçmen kadınların aldıkları manevi desteklerin sosyal ve duygusal yalnızlıkları üzerine etkilerini belirlemek amacıyla görüşme gerçekleştirilen göçmen kadınlara "Birlikte göç ettiğiniz aile üyelerinden bu süreçte aldığınız manevi destekler nelerdir?" ve "Göçe başlarken görmeyi beklediğiniz manevi desteği geldiğinizde bulabildiniz mi?" görüşme soruları sorulmuştur. Görüşmeye katılmayı kabul eden göçmen kadınların tamamı bu sorulara cevap vermişlerdir.

Birlikte göç ettiğiniz aile üyelerinden bu süreçte aldığını manevi destekler nelerdir? sorusuna çalışmaya katılan göçmen kadınlardan birlikte göç ettikleri bireylerden "manevi destek aldığını" ( $N=7-$ \%50,00), "manevi destek alamadığını" ( $\mathrm{N}=5$ - \%35,71) ve "hem manevi destek verdiğini hem de aldığını" (N=2- \%14,29) ifade edenler olmuştur. Göçmen kadınların aile bireylerinden göç sürecinde manevi destek alma durumları ile ilgili bazı ifadeleri aşağıdaki gibidir;

Evet, manevi destek aldım ama bende onlara manevi destek verdim. GK1

Evet, bana manevi destekte çok bulundular. GK4

Ben ve çocuklarım geldik. Başka kimse bizimle gelmedi. Manevi destek alabileceğim kimse yoktu. GK5

Evet, manevi destek aldim ama bende onlara verdim. GK8

Ben tek geldim buraya. Bu nedenle kendime tek destek kendimim. GK13

Göçe başlarken görmeyi beklediğiniz manevi desteği geldiğinizde bulabildiniz mi? sorusuna çalışmaya

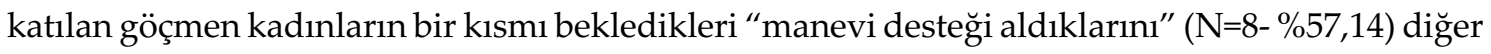
kısmı ise bekledikleri "manevi desteği alamadıklarını" ( $\mathrm{N}=6-\% 42,86)$ ifade etmişlerdir. Göçmen kadınların göçe başlarken görmeyi bekledikleri manevi desteği geldiklerinde bulup bulamama durumları ile ilgili bazı ifadeleri aşağıdaki gibidir;

Hayır, beklediğim manevi desteği alamadım. GK1

Evet, beklediğim manevi desteği aldım. GK2

Hayır, beklediğim manevi desteği almadık. Biz ev kiralamıştık. Kirayı peşim aldı ve sonra bizi evden çıkardı. Bizim paramızı geri vermedi. GK3

Evet, beklediğim manevi desteği aldım. GK4

Evet, aldım ama çocuklarımı bazen dışladılar. GK6

Evet, aldım bana çok konuda destek oldular. GK13

\section{Göçmen Kadınların Göç Etmiş Olmalarına İlişkin Duygu ve Düşüncelerinin Sosyal ve Duygusal Yalnızlıkları Üzerine Etkileri}

Erzurum'da yaşayan göçmen kadınların göç etmiş olmalarına ilişkin duygu ve düşüncelerinin sosyal ve duygusal yalnızlıkları üzerine etkilerini belirlemek amacıyla görüşme gerçekleştirilen göçmen kadınlara "İyi ki bu yolculuğa çıkmışım dedirten kazanımlarınız nelerdir?", "Karşılaştı̆̆ınızda keşke ülkemde kalsaydım demenize neden olan olaylar nelerdir?", "Göçmen bir kadın olmanın zorlukları nelerdir? Göçmen kadın olma deneyiminizi açıklar mısınız?" ve "Erzurum'a göç ettikten sonra en çok neyin eksikliğini hissettiniz?" görüşme soruları 
sorulmuştur. Görüşmeye katılmayı kabul eden göçmen kadınların tamamı bu sorulara cevap vermişlerdir.

İyi ki bu yolculuğa çıkmışım dedirten kazanımlarınız nelerdir? sorusuna çalışmaya katılan göçmen kadınlar genel olarak cevapları iki seçenek altında toplamışlardır. Bunlardan ilki Erzurum'da "can güvenliklerinin olması" ( $\mathrm{N}=13-\% 72,22)$ ikincisi ise "çocuklarının eğitim görebilmesi"dir $(\mathrm{N}=5-\quad \% 27,78)^{3}$. Göçmen kadınlara göç yolculuğuna iyi ki çıkmışım dedirten sebepleri/kazanımları ile ilgili bazı ifadeleri aşağıdaki gibidir;

Çünkü orada düşmanlarım vardı. Hatta kocamı bıçakladılar. Can güvenliğimiz yoktu. GK2

Çünkü benim burada can güvenliğim var. Çocuklarım eğitim görüyor. GK3

Benim yaşadığım yerde savaş vardı ve çocuklarım iyi eğitim görmüyordu o yüzden geldim. GK5

Düşmanlarım vardı benim. Evimi yaktılar kızımı kaçırmaya çalıştılar ve ben kendim baştan sona yandım. GK7

Can güvenliğim yoktu çocuklarım güvende değildi o yüzden geldim. GK8

Ben buraya mecbur olduğum için geldim. Can güvenliğimiz yoktu. GK10

Canım tehlikedeydi çocuklarımın eğitimi için geldim GK12

Çocuklarımın eğitimi için geldim ve orada savaş vardı GK14

Karşılaştığınızda keşke ülkemde kalsaydım demenize neden olan olaylar nelerdir? sorusuna çalışmaya katılan göçmen kadınların tamamı Erzurum'da böyle bir olayla karşılaşmadıklarını, burada mutlu olduklarını ve asla geri dönmek istemediklerini ifade etmişlerdir. Göçmen kadınların karşılaştıklarında keşke ülkemde kalsaydım demesine neden olabilecek olaylar ile ilgili bazı ifadeleri aşağıdaki gibidir;

Hayır, asla öyle bir şey olmadı. GK1

Hayır, ben çok mutluyum. Böyle bir şey yok. GK3

Hayır, ben burada memnunun asla ve asla dönmem. GK4

Hayır karşılaşmadım. Ben ve çocuklarım burada mutluyuz. GK5

Hayır, ben burada çok mutluyum ve dönmeyi düşünmüyorum. GK7

Hayır, asla karşılaşmadım ben buradan çok memnunum. GK8

Göçmen bir kadın olmanın zorlukları nelerdir? Göçmen kadın olma deneyiminizi açıklar mısınız? sorusuna çalışmaya katılan göçmen kadınlar "zorlu yolculuk" (N=13- \%44,82), "kötü konaklama şartları" (N=5- \%17,24), yolda maruz kaldıkları "açlık ve susuzluk" (N=5- \%17,24), "hırsızlık" $(\mathrm{N}=2-\% 6,90)$, "şiddet" ( $\mathrm{N}=2-\% 6,90)$, "eşyalarının kaybolması" ( $\mathrm{N}=1-\% 3,45)$ durumları ve göç sırasında ve sonrasında ortaya çıkan "sağlık problemleri" $(\mathrm{N}=1-\% 3,45)^{4}$ bağlamında cevaplar vermişlerdir. Göçmen kadınların göçmen bir kadın olmanın zorlukları ile ilgili bazı ifadeleri aşağıdaki gibidir;

\footnotetext{
${ }^{3}$ Çalışmaya katılan göçmen kadınlara göç yolculuğuna iyi ki çıkmışım dedirten birden fazla kazanımdan bahseden bulunmaktadır.

${ }^{4}$ Çalışmaya katılan göçmen kadınlardan göçmen bir kadın olmanın birden fazla zorluklarından bahseden bulunmaktadır.
} 
Tam 10 gün yürüdük. Bütün eşyalarımız kayboldu. Bizi polisler yakaladı ve şiddet uyguladı. GK1

Biz çok zorluk çektik 17 gün yürüdük. Biz 10 gün bir ahırda kaldık ve dağlarda uyuduk. Çok zordu. GK2

Çocuklarım çok zorluk çekti ve tam 24 gün yürüdük. Aç ve susuz kaldık. GK3

Tam 10 gün yürüdük ve çocuklarım günlerce aç kaldı. Çok sıkıntılar çektik. İçecek suyumuz bile yoktu. GK5

Bizi yolda hırsızlar yakaladı kocamı dövdüler çocuklarımı dövdüler her şeyimizi aldılar. GK6

Yolda bizi hırsızlar yakaladı bütün eşyalarımızı aldılar. Aç kaldık susuz kaldık 10 gün yürüdük. GK7

Çok zor bir şekilde geldim 17 gün yürüdüm ve kocam yolda hastalandı dağlarda. 5 gün dă̆da kaldık. Kocamın hastalı̆̆ hala devam ediyor. GK8

Erzurum'a göç ettikten sonra en çok neyin eksikliğini hissettiniz? sorusuna çalışmaya katılan göçmen kadınlar; "vatanları" ( $\mathrm{N}=4$ - \%3,45), anne, baba, kardeşleri, akrabaları yani "aileleri" ( $\mathrm{N}=11-\% 3,45)$ ve "çocukları" (N=1- \%3,45)5 olarak ifade etmişlerdir. Göçmen kadınların Erzurum'a göç ettikten sonra eksikliklerini hissettikleri şeyler ile ilgili bazı ifadeleri aşağıdaki gibidir;

Ben vatanımı çok özledim ve oraya dönemiyorum. Burada kalmaya mecburum. GK1

Annemin, babamın, kardeşlerin ve akrabalarımın eksikliğini çektim. GK2

Vatanımı çok özlüyorum ve akrabalarımı özlüyorum ama gidemiyorum. Çünkü savaş var. Can güvenliğimiz yok. GK3

İlk geldiğim zamanlar kocamdan şiddet gördüğü̈m için çocuklarım şiddet gördü̆̆̈̈ için onları yurda aldilar ve ben kendimi çok eksik hissettim. GK5

Annem ve babamı öldürdüler sadece kardeşlerim kaldı onlara çok özlem duyuyorum. GK7

Anne ve babamın, kardeşlerimin hep onların eksikliğini hissediyorum. GK11

Anne, babam ve vatanımın eksikliğini hissettim. GK12

Ailemin eksikliğini hissediyorum. GK13

\section{Göçmen Kadınların Yaşadıklan Sosyal ve Duygusal Yalnızlığın Duygu Durum ve Davranışlarına Etkileri}

Erzurum'da yaşayan göçmen kadınların yaşadıkları sosyal ve duygusal yalnızlığın duygu durum ve davranışlarına etkilerini belirlemek amaciyla görüşme gerçekleştirilen göçmen kadınlara "Yaşadığınız duygusal ve sosyal yalnızlığın ortaya çıkardığı sonuçlar/yansımalar nelerdir?" görüşme sorusu sorulmuştur. Görüşmeye katılmayı kabul eden göçmen kadınların tamamı bu sorulara cevap vermişlerdir.

Yaşadığını duygusal ve sosyal yalnızlı̆̆ın ortaya çıkardı̆̆ı sonuçlar/yansımalar nelerdir? sorusuna çalışmaya katılan göçmen kadınlar; kendilerini "yalnız hissettiklerini" (N=6- \%24,0), “özlem duyduklarını" ( $N=4-\% 16,0)$, yaşadıkları sıkıntılara "çok üzüldüklerini" $(\mathrm{N}=5-\% 20,0)$ bu

\footnotetext{
${ }^{5}$ Çalışmaya katılan göçmen kadınlardan göçmen bir kadın olmanın birden fazla zorluklarından bahseden bulunmaktadır.
} 
nedenlerle de "ağladıklarını" ( $\mathrm{N}=2-\% 8,0)$ ve "bağırdıklarını" ( $\mathrm{N}=1-\% 4,0)$ yani "ruhsal sıkıntıları" $(\mathrm{N}=7-\% 28,0)^{6}$ olduğunu ifade etmişlerdir. Göçmen kadınların yaşadıkları duygusal ve sosyal yalnızlığın ortaya çıkardığı birden fazla sonuç/yansımalar ile ilgili bazı ifadeleri aşağıdaki gibidir;

Çocuklarım için çok üzülüyorum ve kendimi yalnız hissediyorum. Yalnız kaldığımda ă̆lıyorum, bağırıyorum. GK2

Biz burada tek olduğumuz için içim daralıyor ve psikolojim hiç iyi değil. Psikolojik sorunlarım var. GK3

Ben çok yalnız hissediyorum. Bazen kendi kendime ağlıyorum. GK4

Burada tek olduğum için üzülüyorum ama hayat sıkıntılarım da var onlara çok üzülüyorum hem de çok aşırı. GK5

Psikolojik sorunlarım var çok yalnızım. GK7

Ruhsal sıkıntılarım var vatanımı çok özlüyorum ama oraya gidemiyorum. GK8

Kendimi çok yalnız hissediyorum ve ruhsal sikıntılarım var. GK11

Ben burada çok yalnızım ve psikolojim çok bozuk. GK14

\section{Göçmen Kadınların Sosyal ve Duygusal Yalnızlıklarının Kendilerinin Ev Sahibi Olmaları Durumundaki Düşünce ve Davranışları Üzerine Etkileri}

Erzurum'da yaşayan göçmen kadınların sosyal ve duygusal yalnızlıklarının kendilerinin ev sahibi olmaları durumundaki düşünce ve davranışları üzerine etkilerini belirlemek amacıyla görüşme gerçekleştirilen göçmen kadınlara "Siz ev sahibi olsaydınız ve komşularınız göçmen kadınlar olsaydı nasıl davranırdınız?" görüşme sorusu sorulmuştur. Görüşmeye katılmayı kabul eden göçmen kadınların tamamı bu sorulara cevap vermişlerdir.

Siz ev sahibi olsaydınız ve komşularını göçmen kadınlar olsaydı nasıl davranırdınız? sorusuna çalışmaya katılan göçmen kadınlar, "kendilerini göçmen kadının yerine koyarak" (N=2- \%12,50), "göçmen kadın nasıl istiyorsa öyle davranacaklarını" ( $\mathrm{N}=1-\% 6,25)$, "çok iyi davranacaklarını" $(\mathrm{N}=8-\% 50,0)$, "çok merhametli davranacaklarını" $(\mathrm{N}=2-\% 12,50)$ ve "kirasında indirim yapacaklarını" (N=3- \%18,75) ${ }^{7}$ ifade etmişlerdir. Göçmen kadınların ev sahibi olmaları ve komşularının göçmen olması durumundaki davranışları ile ilgili bazı ifadeleri aşağıdaki gibidir;

Ona çok merhametli davranırdım. GK2

Kirasında indirim yapardım ve çok iyi davranırdım çünkü o bizim ülkemizde misafir. GK3

Kendimi onun yerine koyardım ve ne hissettiğini anlardım. GK4

Ben o gö̧̧mene çok iyi davranırdım çünkü o kendi ülkesinden bize sığınmış. GK5

Kendimi onun yerine koyardım ve onun nasll hissettiğini anlardım. GK7

Çok iyi davranırdım istediği kiraya verirdim. GK9

\footnotetext{
${ }^{6}$ Çalışmaya katılan göçmen kadınlardan yaşadıkları duygusal ve sosyal yalnızlığın ortaya çıkardı ̆̆ı birden fazla sonuç/yansımadan bahseden bulunmaktadır.

7 Çalışmaya katılan göçmen ev sahibi olmaları ve komşularının göçmen olması durumundaki sergileyecekleri birden fazla davranıştan bahseden bulunmaktadır.
} 
Kendi istediği bir kiraya verirdim. GK12

Çok merhametli davranırdım. GK14

\section{TARTIŞMA ve SONUÇ}

Çeşitli nedenlerle yaşadıkları yerden ve bireylerden ayrılarak Erzurum'a göç eden kadınların karşılaştıkları ensarlık tutumlarını, göçmen kadın oldukları süreçte yaşadıkları duygusal ve sosyal yalnızlıkları ve bunun üzerinde etkili olan etmenleri ve kendilerinin ensar olmaları durumunda tutumlarının neler olabileceklerinin incelenmesi amaçlayan bu çalışmada 14 göçmen kadınla görüşmeler gerçekleştirilmiştir ve bu görüşmeler neticesinde elde edilen sonuçlar ilgili literatür bağlamında sunulmuştur.

Bu çalışmada göçmen kadınların Erzurum halkı ile arkadaşlık kurmada sıkıntı yaşamadıkları, Erzurum halkından genel olarak memnun oldukları ancak çocuklarının dışlanmaya maruz kaldığı ve dayak yediği sonucuna ulaşılmıştır. Ersoy ve Turan (2019) gerçekleştirdikleri çalışmada sosyal dışlanma ebeveynlere yönelik bile olsa çocukların bunu kendi üzerlerinde hissettiğini ifade etmiştir. Yine aynı çalışmada göçmen öğrencilerin akranları tarafından dışlanmaya maruz kaldıklarını ortaya koymuşlardır. Sosyal dışlanma, güvenceye sahip olmama ve ait olma hissinden yoksun olmayı içinde barındırmaktadır. Dışlanan bireylerin topluma uyum sürecinde de sıkıntılar yaşanmaktadır. Ayrıca bu çalışmada ev kiralama ve evden taşınma durumlarında para iadesi alma konularında sıkıntı yaşadıklarını ifade ettikleri görülmüştür. Çalışmada göçmen kadınların tamamının diğer mültecilerle arkadaşlık kurmada ve diğer ilişkilerinde bir sıkıntı yaşamadıkları saptanmıştır.

Türkiye' de göçmenler yerel halkın hem kültürü hem de iş imkanları açısından birer tehdit olarak görülmesine (Ünal, 2014) karşın bu çalışmada göçmen kadınların Erzurum halkının kendilerine çok yardımcı olduklarını kendilerini çok sevdiklerini bu nedenle kendilerini anladıklarını düşündükleri sonucuna ulaşılmıştır. Ancak göçmen kadınların bir kısmı yerel halkın tam anlamıyla kendilerini anlamadığı, diğer bir kısmı ise hiç anlamadığını düşündüğü de görülmüştür.

Göçmen kadınlar göçe başlarken hem göç yolculuğunda yanında olan bireylerden hem de göç sonucunda vardıkları yerde almayı bekledikleri manevi destekler vardır. Bunda hem göçe çıktıları bireylerin özellikleri ve kendilerine yakınlık dereceleri etkiliyken hem de göç sonucunda varacakları yerin dini ve kültürel özellikleri de etkili olmaktadır. Bu çalışmada göçmen kadınların göç yolculuğuna başlarken yanlarında olan bireylerden bekledikleri manevi desteği genelde aldıkları aynı zamanda kendilerinin de yanlarındaki bireylere manevi destek verdikleri saptanmıştır. Ayrıca göçe sonucunda vardıkları yerde bekledikleri desteği aldıkları ve alamadıkları durumlarla karşılaştıkları da görülmüştür.

$\mathrm{Bu}$ çalışmada göçmen kadınların iyi ki göç yolculuğuna çıkmışım demelerinde can güvenliklerinin olması ve çocuklarının eğitim imkanlarının olmasının önemli etkenler olduğu tespit edilmiştir. Ancak Börü ve Boyacı'ya (2016) göre göçmen öğrenciler okulda dil, ekonomi ve ailesel sorunlarla baş etmek zorunda kalmaktadır. Eğitimde öğrencilerin Türkçe dil bilgi ve becerilerinin yerli öğrenciler kadar iyi olmaması onların eğitim süreçlerinde dezavantajlı konuma geçmesine neden olmaktadır. Ayrıca ailelerin ekonomik ve diğer problemleri de öğrencilerin eğitimleri ile ilgilenilme süresini ve düzeyini etkilediği için yine eğitimlerini etkileyen olumsuz bir sorun olarak karşılarına çıkmaktadır (Kaştan, 2015; Topsakal, Merey ve Keçe, 2013). Ayrıca çalışmaya katılan göçmen kadınların tamamı Erzurum'da keşke gelmeseydim demelerine ya da 
pişman olmalarına neden olabilecek bir olayla karşılaşmadıklarını, burada mutlu olduklarını ve asla geri dönmek istemediklerini dile getirmişlerdir.

Çalışmaya katılan göçmen kadınlar kötü konaklama şartları, yolda maruz kaldıkları açlık ve susuzluk, hırsızlık, şiddet, eşyalarının kaybolması durumları ve göç sırasında ve sonrasında ortaya çıkan sağlık problemleri nedeniyle göçü zorlu bir yolculuk olarak tanımlamış ve kendileri bunu göçmen kadın olmanın gerçeği olarak görmüşlerdir. Hem göçmen olmalarından hem de zorlu bir yolculuk yaşamalarından dolayı göçmen kadınların kendilerini yalnız hissettikleri, ailelerine/vatanlarına özlem duydukları, yaşadıkları sıkıntılara çok üzüldükleri bu nedenlerle de ağladıkları ve bağırdıkları yani ruhsal sıkıntıları olduğunu görülmüştür.

Çalışmaya katılan göçmen kadınların ev sahibi olmaları ve komşularının göçmen olmaları durumunda kendilerini göçmen kadının yerine koyarak, göçmen kadın nasıl istiyorsa öyle davranacaklarını, çok iyi ve çok merhametli davranacaklarını ve kirasında indirim yapacaklarını ifade ettikleri görülmüştür.

$\mathrm{Bu}$ çalışma neticesinde göçmenlerin toplumla özellikle çocukların entegrasyonu ile ilgi uyum, ait olma ve kabul konularındaki çalışmaların yanı sıra göçmen kadınların psikolojik durumlarını ve göç sürecinin zorlukları sonucunda ortaya çıkan rahatsızlıkların giderilebilmesi için psikolojik destek programları/uygulamaları gerçekleştirilmesi önerilmektedir.

\section{KAYNAKLAR}

Börü, N. ve Boyacı, A. (2016). Göçmen Öğrencilerin Eğitim-Öğretim Ortamlarında Karşılaştıkları Sorunlar: Eskişehir İli Örneği. Turkish Studies, 11(14), 123-158.

Cresswell, J.W. (2013). Nitel Araştırma Yöntemleri (3.Baskıdan Çev. Selçuk Beşir Demir). Ankara: Siyasal Kitapevi.

Erder, S. (1986). Refah Toplumunda 'Getto' ve Türkler. İstanbul: Teknografik Matbaacilık.

Ersoy, A. F. ve Turan, N. (2019). Sığınmacı ve Göçmen Öğrencilerde Sosyal Dışlanma ve Çeteleşme. Üçüncü Sektör Sosyal Ekonomi Dergisi, 54(2), 828-840.

Fleury, A. (2016). Understanding Women and Migration: A Literature Review, KNOMAD Working Paper 8.

Kaştan, Y. (2015). Türkiye' de Göç Yaşamış Çocukların Eğitim Sürecinde Karşılaşılan Problemler. Uluslararası Sosyal ve Eğitim Bilimleri Dergisi, 2(4), 216-229.

Koç Başaran, Y. (2017). Sosyal Bilimlerde Örnekleme Kuramı. Akademik Sosyal Araştırmalar Dergisi, 5(47), 480-495.

Mollard, B. (2010). Kadın ve Göç: Göç Deneyimi Boyunca Sağhlğın Geliştirilmesi, Göç ve Kadın Sempozyumu, 11 Mart 2010, Hacettepe Üniversitesi Nüfus Etütleri Enstitüsü, Ankara.

Neuman, W. L. (2012). Toplumsal Araştırma Yöntemleri: Nicel ve Nitel Yaklaşımlar I-II. Cilt. 5. Basım. İstanbul: Yayın Odası Yayınları.

Topsakal, C., Merey, Z. ve Keçe, M. (2013). Göçle Gelen Ailelerin Çocuklarının Eğitim-Öğrenim Hakkı ve Sorunları Üzerine Nitel Bir Çalışma. Uluslararası Sosyal Araştırmalar Dergisi, 6(27), 539553.

UNCHR. (2018). Figures at a Glance. https://www.unhcr.org/figures-at-a-glance.html. Erişim Tarihi: 13.07.2021

United Nations (2017). International Migration Report. New York: United Nations. 
UNODC. (2016). Global Report on Trafficking in Persons. https://www.unodc.org/unodc/dataand-analysis/glotip.html. Erişim Tarihi: 13.07.2021

Ünal, S. (2014). Türkiye'nin Beklenmedik Konukları: “Öteki” Bağlamında Yabancı Göçmen ve Mülteci Deneyimi. Journal of World of Turks, 6(3), 65-89.

Yıldırım, A. ve Şimşek, H. (2010). Sosyal Bilimlerde Nitel Araştırma Yöntemleri. 10. Baskı. Ankara: Seçkin Yayıncılık.

Yılmaz, A. (2019). Göç ve Kadın: 'Göçün Feminizasyonu' ve Kadın Göçmenlerin Durumu. CBÜ Sosyal Bilimler Dergisi, 17(1), 383-400. 